\title{
Selection Criteria for Holstein Friesian and Crossbreed Dairy Cattle Objective Traits in Ethiopia
}

\author{
Amare Berhe Kidane ${ }^{1,2^{*}}$, Kefena Effa Delesa ${ }^{3}$, Yesihak Yusuf Mummed ${ }^{2}$, Million Tadesse Tegegn ${ }^{4}$ \\ ${ }^{1}$ Samara University, Samara, Ethiopia \\ ${ }^{2}$ Haramaya University, Haramaya, Ethiopia \\ ${ }^{3}$ International Livestock Research Institution (ILRI), Addis Ababa, Ethiopia \\ ${ }^{4}$ Ethiopian Institute of Agricultural Research (EIAR), Holeta, Ethiopia \\ Email: ^kidaneamare@su.edu.et
}

How to cite this paper: Kidane, A.B., Delesa, K.E., Mummed, Y.Y. and Tegegn, M.T. (2019) Selection Criteria for Holstein Friesian and Crossbreed Dairy Cattle Objective Traits in Ethiopia. Open Journal of Animal Sciences, 9, 429-460.

https://doi.org/10.4236/ojas.2019.94034

Received: August 6, 2019

Accepted: October 5, 2019

Published: October 8, 2019

Copyright $\odot 2019$ by author(s) and Scientific Research Publishing Inc. This work is licensed under the Creative Commons Attribution International License (CC BY 4.0).

http://creativecommons.org/licenses/by/4.0/

\begin{abstract}
There was no research regarding selection criteria for the economically relevant dairy cattle objective traits in Ethiopia. Therefore, the goal of this paper was to determine the selection criteria for Holstein Friesian and crossbreed dairy cattle economically relevant traits. The research was based on 236 respondents of large, medium and small scale dairy farms from Dire-Dawa, Harar, Bishoftu, Holeta agricultural research center and Mekele. Data were analyzed using statistical analysis software and traits preferences were ranked by calculating index values with the principle of weighted average. For Holstein Friesian producers, the most preferred breeds were pure Holstein Friesian, Holstein Friesian crossbreeds and local cattle breeds with an overall index value of $0.47,0.36$, and 0.13 , respectively. Similarly for crossbreed producers, pure Holstein Friesian (0.46), Holstein Friesian crossbreed (0.37) and local cattle (0.15), respectively, were their main breed preferred. In the present study, both Holstein Friesian and crossbreed producers were used milk yield (0.61, and 0.64$)$ and milk yield composition ( 0.39 , and 0.34 ), as the main preferred selection criteria for milk composition, respectively. On the other situations, age at first calving (0.45, and 0.39), age at first service $(0.38$, and 0.37$)$, and service per conception (0.08, and 0.17$)$, were the preferred selection criteria for economically relevant reproduction traits both for Holstein Friesian and crossbreed, respectively.
\end{abstract}

\section{Keywords}

Dairy Cattle, Economically Relevant Traits, Selection Criteria 


\section{Introduction}

Ethiopia is known for its huge livestock population and is estimated to have 59.5 million heads of cattle, 30.6 million sheep, 30.2 million goats, 59.5 million of poultry, 2.16 million horses, 8.43 million donkeys and 1.21 million camels, respectively [1]. Livestock production makes an essential contribution to agriculture, food and rural development. They provide products and services such as milk, meat, draught power and manure for fertilizers and fuel [2]. As compared to its potential and contribution to the Ethiopian economy, the livestock sector is less productive and production per animal is extremely low [3]. Milk production and reproductive traits are crucial factors and they are determinant for the profitability of dairy production [4].

Breeding is aimed at changing the genetic merit of animals in the coming generations such that, they will produce the desired products more efficiently (relative to the present generation) under future economic, natural and social circumstances [5]. Breeding objective is defined as the reason (s) for which animals are specifically bred for, it assumes that the farmers have made a deliberate choice to genetically improve the next generation of animals in terms of their performance in relation to their parent generations [6]. The basic principle of any industry is the generation of efficient and productive results that lead to maximized economic returns [7]. The definition of selection objectives for a combination of economically important traits should be the first step in implementing a breeding program [8] [9] [10]. The selection criteria are the basis for formulating the profit equation, from which the economic values are derived [11]. Selection criteria are those traits that can be measured on the animal and can also be used as predictors of the traits included in the breeding objectives [12]. Traits included in the breeding objectives (i.e. economically relevant traits) may be the same or different from the selection criteria. When the objective trait and selection criterion are different, the selection criteria are known as an indicator trait. An indicator trait is a trait that is used to indicate the merit of an animal for another trait [13].

The estimated breeding value of an observed trait can be readily calculated as a linear function of the estimated breeding value for measured trait (s) [14]. Many economically relevant traits in dairy cattle are difficult to measure and therefore need to be predicted by indicator traits. The value of an indicator trait will depend largely on the magnitude of co-heritability and genetic correlation between the objective trait and the indicator trait [15]. In the Ethiopian dairy farms, there is no information on selection criteria for dairy cattle objectives traits. So, the present study was focused on selection criteria of dairy cattle objective traits both for Holstein Friesian and crossbreed dairy cattle breeds.

\section{Material and Methods}

\subsection{Description of the Study Area}

The study was conducted at the selected large, medium and small scale dairy 
farms at Dire Dawa, Harar, Bishoftu dairy farms and Mekele (Figure 1). Moreover, institutional dairy farms at Haramaya University and Holeta agricultural research center were used for the study.

\section{Dire Dawa}

Dire Dawa is geographically located in eastern parts of Ethiopia between $9^{\circ} 27^{\prime} \mathrm{E}$ and $49^{\prime} \mathrm{N}$ latitude and between $41^{\circ} 38^{\prime} \mathrm{N}$ and $19^{\prime} \mathrm{E}$ longitude and is located $515 \mathrm{~km}$ away from Addis Ababa [16]. Topographically, it is a dissected mountainous region with the mountain ranges located in the southern part. Dire dawa has a bimodal rainfall with the mean annual rainfall varying from $550 \mathrm{~mm}$ in the northern lowlands to about $850 \mathrm{~mm}$ in the southern mountains. The mean annual maximum and minimum temperatures of the town are $31.4^{\circ} \mathrm{C}$ and $18.41^{\circ} \mathrm{C}$, respectively [17]. The total human population of the town is estimated at 288,000 with a growth rate of $2.5 \%$ [18].

\section{Harar}

The Harari region is one of the nine administrative regions of Ethiopia. Harari National Regional State is located at a distance of $525 \mathrm{~km}$ eastern of Addis Ababa [19]. The Harari region lies between latitude $9^{\circ} 24^{\prime} \mathrm{N}$ and $9^{\circ} 42^{\prime} 03^{\prime \prime} \mathrm{E}$ and $42^{\circ} 16^{\prime} \mathrm{E}$ longitude. The Harari region has a wet tropical and receives an annual rainfall between $596 \mathrm{~mm}$ and $900 \mathrm{~mm}$ in a bimodal pattern. It is located at an altitude of 1850 meters above sea level and has a mean annual maximum and minimum temperature of 25 and $10^{\circ} \mathrm{C}$, respectively [20]. The total human population of the town is estimated at 125,000 with a growth rate of $2.6 \%$ [18].

\section{Bishoftu}

Bishoftu is a town and separate district located in the East Shewa zone at a distance of $45 \mathrm{~km}$ South East of Addis Ababa, Ethiopia. The town is located in east Showa zone of Oromia region and it lies $9^{\circ}$ North latitude and $40^{\circ}$ East longitude at an altitude of 1850 meters above sea level in the central high land of Ethiopia. It has an annual rainfall of $866 \mathrm{~mm}$ of which $84 \%$ is in the long rainy season (June to September) and the remaining in the short rainy season extending from March to May. The mean annual maximum and minimum temperatures of the area are $26^{\circ} \mathrm{C}$ and $14^{\circ} \mathrm{C}$, respectively, with mean relative humidity of $61.3 \%$ [21].

\section{Holota}

Holota is a town and separate district in the Oromia special zone surrounding Finfinnee. The town is located $40 \mathrm{~km}$ west of Addis Ababa at $9^{\circ} 30^{\prime} \mathrm{N}$ and $38^{\circ} 30^{\prime} \mathrm{E}$ with altitude range from 2300 - 3800 meters above sea level. The annual mean temperature ranges from $14^{\circ} \mathrm{C}$ to $24^{\circ} \mathrm{C}$ and annual rainfall ranges from 900 $1100 \mathrm{~mm}$. According to the population and housing censes of 2007 the population of the town is 23,296 (male $=11,512$, female $=11,784)$. $(49.41 \%$ male and $50.59 \%$ female) [18].

\section{Mekele}

Mekelle, the regional capital city of the Tigray region, commonly known as Semenawit Kokob to mean the star of north is one of the largest cities in Ethiopia which is located in the northern Ethiopia high lands at $777 \mathrm{~km}$ drive north 
of national capital city, Addis Ababa. Geographically, the city is situated between $13^{\circ} 29^{\prime} \mathrm{N} 39^{\circ} 28^{\prime} \mathrm{E}$ latitude and $13.48^{\circ} \mathrm{N} 39.47^{\circ} \mathrm{E}$ longitude. It has an average altitude of 2084 meters above sea level with a mean minimum, mean maximum and mean average monthly temperatures of $8.7^{\circ} \mathrm{C}, 26.8^{\circ} \mathrm{C}$ and $17.6^{\circ} \mathrm{C}$, respectively [22]. Mekelle has an estimated total population of 215,546 [23].

\subsection{Sampling Strategy and Data Collection}

The study was conducted at large, medium and small scale dairy farms of Diredawa, Harar, Bishoftu, Hollota agricultural research center and Mekele dairy farms. Dairy cattle producers were classified on the basis of the number of dairy cows they owned and level of input for their dairy farms. Before the actual work was started, focused group discussions were held with the different experts working at the regional and zonal agricultural development office. Discussions were also made with dairy cattle owners. The total number of households interviewed on the dairy production system was 236 respondents. Semi-structured

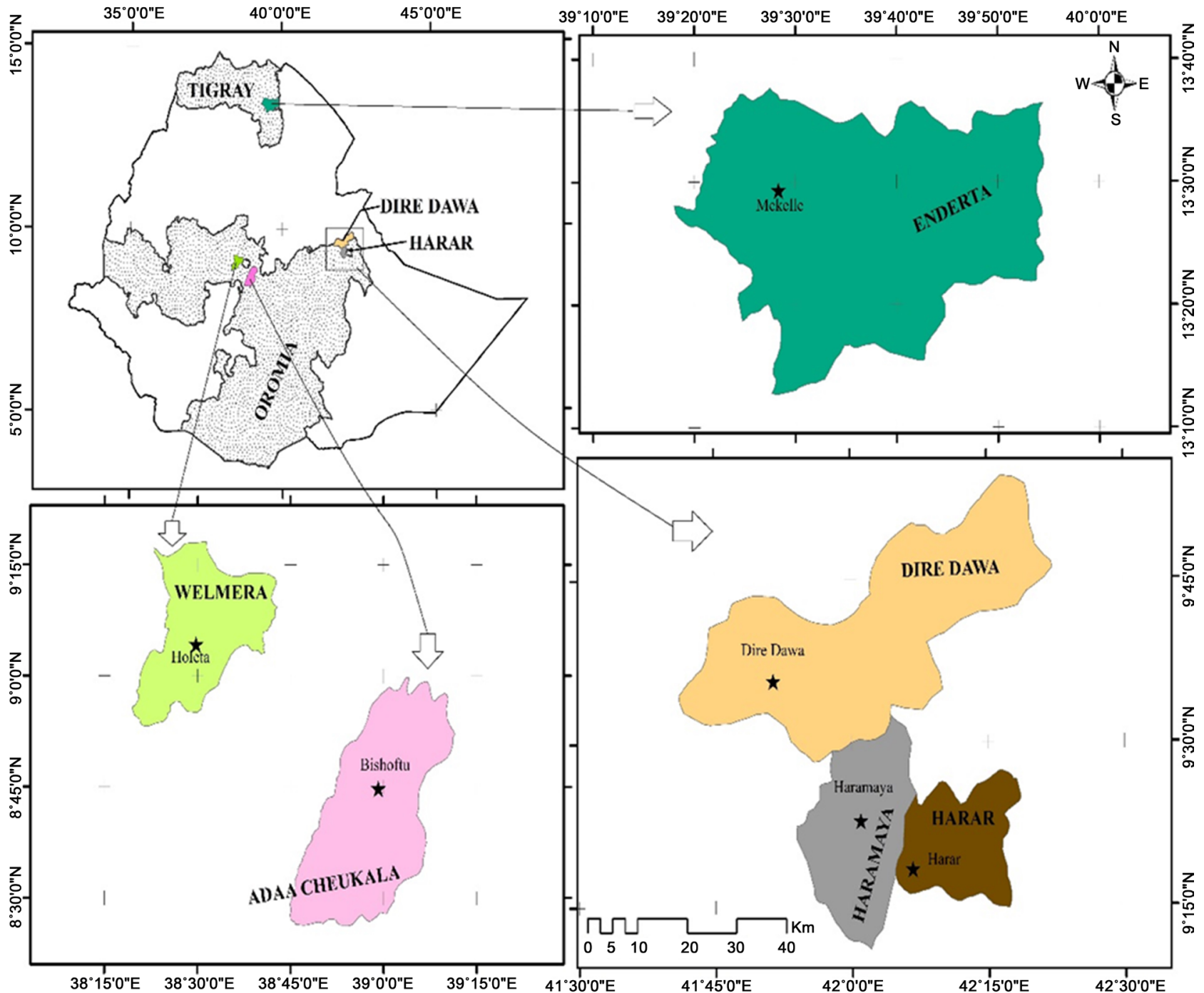

Figure 1. Map of study area. 
questionnaire and formal interviews were used to collect information from the selected households. The questionnaire was tested before the actual survey to ensure that all questions were sufficiently clear for the interviewees. Data on the genera breed preferences, culling criteria and selection criteria for economically relevant traits were collected by trained enumerators.

\subsection{Data Analysis}

Statistical analysis software [24] was used to describe the general household characteristics across all the production systems. Preference ranking was ranked by calculating index values with the principle of weighted average according to the following formula.

$$
\text { Index }=\left(R_{n} \times C_{1}+R_{n-1} \times C_{2}+\cdots+R_{1} \times C_{n}\right) / \sum\left(R_{n} \times C_{1}+R_{n-1} \times C_{2}+\cdots+R_{1} \times C_{n}\right)
$$

where, $R_{n}=$ the last rank. $C_{n}=$ the $\%$ of respondents in the last rank, $C_{1}=$ the $\%$ of respondents ranked first

\section{Results and Discussions}

\subsection{Dairy Cattle Breed Preferences}

Breed preferences for Holstein Friesian and crossbreed dairy cattle producers are presented in Table 1 and Table 2. For the large scale Holstein Friesian dairy producers, pure Holstein Friesian, Holstein Friesian crossbreed and Jersey crossbreed dairy cattle were the main breed preferred with an index value of 0.45 , 0.38 and 0.06 , respectively. On the other hand for the medium and small scale dairy producers, pure Holstein Friesian, Holstein Friesian crossbreed and local dairy cattle breeds were the main breed preferences with a mean index value of $0.47,0.48,0.36,0.35$ and $0.17,0.17$, for medium and small scale, respectively. Similar to the medium and small scale Holstein Friesian dairy cattle producers, pure Holstein Friesian $(0.49,0.45$ and 0.44), Holstein Friesian crossbreed (0.34,

Table 1. Ranking of breed preferences for Holstein Friesian dairy cattle producers.

\begin{tabular}{|c|c|c|c|c|c|c|c|c|c|c|c|c|c|}
\hline \multirow{3}{*}{ Breeds } & \multicolumn{12}{|c|}{ Holstein Friesian dairy cattle producers } & \multirow{3}{*}{$\begin{array}{c}\text { Overall } \\
\text { index }\end{array}$} \\
\hline & \multicolumn{4}{|c|}{ Large scale } & \multicolumn{3}{|c|}{ Medium scale } & \multicolumn{5}{|c|}{ Small scale } & \\
\hline & $\mathrm{R} 1$ & $\mathrm{R} 2$ & R3 & I & R1 & $\mathrm{R} 2$ & R3 & I & $\mathrm{R} 1$ & $\mathrm{R} 2$ & R3 & I & \\
\hline $\begin{array}{l}\text { Pure Holstein } \\
\text { Frisian }\end{array}$ & $75.00(15)$ & $\begin{array}{c}20.00 \\
(4)\end{array}$ & $\begin{array}{c}5.00 \\
(1)\end{array}$ & 0.45 & $\begin{array}{c}82.50 \\
(33)\end{array}$ & $\begin{array}{c}17.50 \\
(7)\end{array}$ & 0.00 & 0.47 & $\begin{array}{c}90.00 \\
(27)\end{array}$ & $\begin{array}{c}10.00 \\
(3)\end{array}$ & 0.00 & 0.48 & 0.47 \\
\hline Pure jersey & 0.00 & $5.00(1)$ & $\begin{array}{c}30.00 \\
(6)\end{array}$ & 0.02 & 0.00 & 0.00 & 0.00 & 00.00 & 0.00 & 0.00 & 0.00 & 0.00 & 0.01 \\
\hline $\begin{array}{l}\text { Holstein Friesian } \\
\text { crossbreed }\end{array}$ & $25.00(5)$ & $\begin{array}{c}75.00 \\
(15)\end{array}$ & 0.00 & 0.38 & $\begin{array}{c}17.50 \\
(7)\end{array}$ & $\begin{array}{c}82.50 \\
(33)\end{array}$ & 0.00 & 0.36 & $\begin{array}{c}10.00 \\
(3)\end{array}$ & $\begin{array}{l}90.00 \\
(27)\end{array}$ & 0.00 & 0.35 & 0.36 \\
\hline Jersey crossbred & 0.00 & 0.00 & $\begin{array}{c}35.00 \\
(7)\end{array}$ & 0.06 & 0.00 & 0.00 & 0.00 & 0.00 & 0.00 & 0.00 & 0.00 & 0.00 & 0.02 \\
\hline Local breeds & 0.00 & 0.00 & $\begin{array}{c}30.00 \\
(6)\end{array}$ & 0.05 & 0.00 & 0.00 & $\begin{array}{c}100.00 \\
(20)\end{array}$ & 0.17 & 0.00 & 0.00 & $\begin{array}{c}100.00 \\
(20)\end{array}$ & 0.17 & 0.13 \\
\hline
\end{tabular}

Note: $\mathrm{R} 1=\operatorname{rank} 1, \mathrm{R} 2=\operatorname{rank} 2, \mathrm{R} 3=\operatorname{rank} 3, \mathrm{I}=$ index. 
Table 2. Ranking of breed preferences for crossbreed dairy cattle producers.

\begin{tabular}{|c|c|c|c|c|c|c|c|c|c|c|c|c|c|}
\hline \multirow{3}{*}{ Breeds } & \multicolumn{12}{|c|}{ Crossbreed dairy cattle producers } & \multirow{3}{*}{$\begin{array}{l}\text { Overall } \\
\text { index }\end{array}$} \\
\hline & \multicolumn{4}{|c|}{ Large scale } & \multicolumn{4}{|c|}{ Medium scale } & \multicolumn{4}{|c|}{ Small scale } & \\
\hline & $\mathrm{R} 1$ & $\mathrm{R} 2$ & R3 & I & $\mathrm{R} 1$ & $\mathrm{R} 2$ & R3 & I & $\mathrm{R} 1$ & $\mathrm{R} 2$ & R3 & I & \\
\hline $\begin{array}{l}\text { Pure Holstein } \\
\text { Frisian }\end{array}$ & $\begin{array}{c}95.00 \\
(19)\end{array}$ & $\begin{array}{l}5.00 \\
(1)\end{array}$ & 0.00 & 0.49 & $\begin{array}{c}68.89 \\
(31)\end{array}$ & $\begin{array}{c}31.11 \\
(14)\end{array}$ & 0.00 & 0.45 & $\begin{array}{c}61.73 \\
(50)\end{array}$ & $\begin{array}{r}38.27 \\
(31)\end{array}$ & 0.00 & 0.44 & 0.46 \\
\hline $\begin{array}{l}\text { Holstein Friesian } \\
\text { crossbred }\end{array}$ & $\begin{array}{c}5.00 \\
(1)\end{array}$ & $\begin{array}{c}95.00 \\
(19)\end{array}$ & 0.00 & 0.34 & $\begin{array}{c}31.11 \\
(14)\end{array}$ & $\begin{array}{c}68.89 \\
(31)\end{array}$ & 0.00 & 0.38 & $\begin{array}{r}38.27 \\
(31)\end{array}$ & $\begin{array}{c}61.73 \\
(50)\end{array}$ & 0.00 & 0.40 & 0.37 \\
\hline Jersey crossbred & 0.00 & 0.00 & 0.00 & 0.00 & 0.00 & 0.00 & 0.00 & 0.00 & 0.00 & 0.00 & $\begin{array}{c}40.74 \\
(33)\end{array}$ & 0.06 & 0.02 \\
\hline Local breeds & 0.00 & 0.00 & $\begin{array}{c}100.00 \\
(20)\end{array}$ & 0.17 & 0.00 & 0.00 & $\begin{array}{c}100.00 \\
(20)\end{array}$ & 0.17 & 0.00 & 0.00 & $\begin{array}{c}59.26 \\
(48)\end{array}$ & 0.10 & 0.15 \\
\hline
\end{tabular}

Note: $\mathrm{R} 1=\operatorname{rank} 1, \mathrm{R} 2=\operatorname{rank} 2, \mathrm{R} 3=\operatorname{rank} 3, \mathrm{I}=$ index.

0.38 and 0.40$)$ and local breeds $(0.17,0.17$, and 0.10$)$ were the main breed preferred for large medium and small scale crossbreed dairy producers, respectively. The results revealed that majority of the respondents in the study with area were greatly attached with pure Holstein Friesian and Holstein Friesian crossbreed dairy cows. This was found to be in line with their objectives of dairy farming, which milk production was as source of income generation. Unlike to the current study farms, farms in the Jimma town, Ethiopia would prefer to crossbreed cows with high milk production, high fertility and longs lactation length [25].

\subsection{Reasons for Preferring Holstein Friesian and Crossbreed Dairy Cattle}

Under the Ethiopian dairy production system where milk is sold on volume basis, high milk yield is the most important criteria for selecting a specific dairy cattle breed. The reasons for preferring Holstein Friesian and crossbreed dairy cattle are present in Table 3 and Table 4. For the Holstein Friesian dairy producers, high milk yield $(0.41,0.43$ and 0.46$)$, high reproductive efficiency $(0.24$, 0.33 and 0.25$)$ and fast growth rate $(0.22,0.25$, and 0.23$)$ were the most preferred traits for large, medium and small scale dairy farms, respectively. Unlike the Holstein Friesian dairy producers, high milk yield (0.44 and 0.43$)$, fast growth rate (0.39 and higher reproductive efficiency $(0.23$ and 0.20$)$ were the most preferred traits for the large and small scale crossbreed dairy producer, respectively. on the other hand, similar to the large scale Holstein friesian producers, high milk yield, high reproductive efficiency and fast growth rate were the main preferring traits for crossbreed dairy cattle in the medium scale crossbreed dairy producers with an index value of $0.43,0.33$ and 0.23 , respectively. the current study showed that the reasons for preferring crossbreed dairy producers was different from [25] who reported that milk yield (0.26), fertility (0.23), lactation length (0.22) and longevity (0.14) were the main reasons for ranking crossbreed cows in the small holder dairy farms of Jimma town, Ethiopia. 
Table 3. Reasons for preferring Holstein Friesian breeds.

\begin{tabular}{|c|c|c|c|c|c|c|c|c|c|c|c|c|}
\hline \multirow{3}{*}{ Traits } & \multicolumn{12}{|c|}{ Holstein Friesian dairy cattle owners } \\
\hline & \multicolumn{4}{|c|}{ Large scale } & \multicolumn{4}{|c|}{ Medium scale } & \multicolumn{4}{|c|}{ Small scale } \\
\hline & R1 & $\mathrm{R} 2$ & R3 & I & R1 & $\mathrm{R} 2$ & $\mathrm{R} 3$ & I & $\mathrm{R} 1$ & $\mathrm{R} 2$ & $\mathrm{R} 3$ & I \\
\hline HMY & $70.00(14)$ & $25.00(5)$ & $5.00(1)$ & 0.41 & $55.00(22)$ & $45.00(18)$ & 0.00 & 0.43 & $76.67(23)$ & $20.0(6)$ & $3.33(1)$ & 0.46 \\
\hline LBS & 0.00 & 0.00 & $5.00(1)$ & 0.01 & 0.00 & 0.00 & 0.00 & 0.00 & 0.00 & $6.67(2)$ & $6.67(2)$ & 0.03 \\
\hline HFCE & $5.00(1)$ & $5.00(5)$ & $10.00(2)$ & 0.12 & 0.00 & 0.00 & 0.00 & 0.00 & 0.00 & 0.00 & 0.00 & 0.00 \\
\hline BY & 0.00 & 0.00 & 0.00 & 0.00 & 0.00 & 0.00 & 0.00 & 0.00 & 0.00 & 0.00 & 0.00 & 0.00 \\
\hline HRE & $20.00(4)$ & $25.00(5)$ & $45.00(9)$ & 0.24 & $30.00(12)$ & $37.50(15)$ & $32.50(13)$ & 0.33 & $23.33(7)$ & $23.33(7)$ & $33.33(10)$ & 0.25 \\
\hline HDR & 0.00 & 0.00 & 0.00 & 0.00 & 0.00 & 0.00 & 0.00 & 0.00 & 0.00 & 0.00 & 0.00 & 0.00 \\
\hline FGR & $5.00(1)$ & $45.00(9)$ & $40.00(8)$ & 0.22 & $15.00(6)$ & $17.50(7)$ & $67.50(27)$ & 0.25 & 0.00 & $43.33(13)$ & $53.33(16)$ & 0.23 \\
\hline $\mathrm{DF}$ & 0.00 & 0.00 & 0.00 & 0.00 & 0.00 & 0.00 & 0.00 & 0.00 & 0.00 & 0.00 & 0.00 & 0.00 \\
\hline GL & 0.00 & 0.00 & 0.00 & 0.00 & 0.00 & 0.00 & 0.00 & 0.00 & 0.00 & 0.00 & 0.00 & 0.00 \\
\hline Tem & 0.00 & 0.00 & 0.00 & 0.00 & 0.00 & 0.00 & 0.00 & 0.00 & 0.00 & $6.67(2)$ & $3.33(1)$ & 0.03 \\
\hline
\end{tabular}

Table 4. Reasons for preferring crossbreeds.

\begin{tabular}{|c|c|c|c|c|c|c|c|c|c|c|c|c|}
\hline \multirow{3}{*}{ Breeds } & \multicolumn{12}{|c|}{ Crossbreed dairy cattle owner } \\
\hline & \multicolumn{4}{|c|}{ Large scale } & \multicolumn{4}{|c|}{ Medium scale } & \multicolumn{4}{|c|}{ Small scale } \\
\hline & $\mathrm{R} 1$ & $\mathrm{R} 2$ & R3 & I & $\mathrm{R} 1$ & $\mathrm{R} 2$ & R3 & I & $\mathrm{R} 1$ & $\mathrm{R} 2$ & R3 & I \\
\hline HMY & $70.00(14)$ & $25.00(5)$ & $5.00(1)$ & 0.44 & $60.0(27)$ & $40.0(18)$ & 0.00 & 0.43 & $80.25(65)$ & $16.05(13)$ & $3.70(3)$ & 0.46 \\
\hline LBS & 0.00 & $10.00(2)$ & $10.00(2)$ & 0.05 & 0.00 & 0.00 & 0.00 & 0.00 & 0.00 & $1.23(1)$ & $8.64(7)$ & 0.02 \\
\hline HFCE & 0.00 & 0.00 & 0.00 & 0.00 & 0.00 & 0.00 & 0.00 & 0.00 & 0.00 & 0.00 & 0.00 & 0.00 \\
\hline BY & 0.00 & 0.00 & 0.00 & 0.00 & 0.00 & 0.00 & 0.00 & 0.00 & 0.00 & 0.00 & 0.00 & 0.00 \\
\hline HRE & $30.00(6)$ & $10.00(2)$ & $30.00(6)$ & 0.23 & $24.44(11)$ & $51.11(23)$ & $24.44(11)$ & 0.33 & $14.81(12)$ & $22.22(18)$ & $33.33(27)$ & 0.20 \\
\hline HDR & 0.00 & 0.00 & 0.00 & 0.00 & 0.00 & 0.00 & 0.00 & 0.00 & 0.00 & 0.00 & 0.00 & 0.00 \\
\hline FGR & $45.00(9)$ & $50.00(10)$ & 0.00 & 0.39 & $15.56(7)$ & $8.89(4)$ & $75.56(34)$ & 0.23 & $4.94(4)$ & 48.15 (39) & $45.68(37)$ & 0.26 \\
\hline $\mathrm{DF}$ & 0.00 & 0.00 & 0.00 & 0.00 & 0.00 & 0.00 & 0.00 & 0.00 & 0.00 & 0.00 & $1.23(1)$ & 0.00 \\
\hline GL & 0.00 & 0.00 & 0.00 & 0.00 & 0.00 & 0.00 & 0.00 & 0.00 & 0.00 & 0.00 & 0.00 & 0.00 \\
\hline Tem & $10.00(2)$ & $5.00(1)$ & 0.00 & 0.00 & 0.00 & 0.00 & 0.00 & 0.00 & 0.00 & $11.11(9)$ & $8.64(7)$ & 0.05 \\
\hline
\end{tabular}

Note: $\mathrm{R} 1=\operatorname{rank} 1, \mathrm{R} 2=\operatorname{rank} 2, \mathrm{R} 3=\operatorname{rank} 3, \mathrm{I}=$ index, $\mathrm{HMY}=$ high milk yield, $\mathrm{LBS}=$ large body size, $\mathrm{HFCE}=$ high feed conversion efficiency, $\mathrm{BY}=$ butter yield, HRE $=$ high reproductive efficiency, HDR $=$ high disease resistance, $\mathrm{FGR}=$ fast growth rate, $\mathrm{DF}=$ dairy form $/$ type, GL $=$ good longevity, Tem $=$ good temperament.

\subsection{Culling Criteria of Holstein Friesian and Crossbreed Dairy Cows}

Culling is one of the most complicated decisions that dairy producers make on an almost day-to-day basis. Culling is the act of removing animals from a livestock production enterprise. The culling criteria for Holstein Friesian and cros- 
sbreed dairy cows are presented in Table 5 and Table 6. In the study areas, respondents were practiced both voluntary and involuntary culling. For the Holstein Friesian dairy cattle producers, health problem, old age, late calving interval and late age at first services were the main criteria for culling dairy cows. In the large Holstein Friesian dairy producers, respondents cull their animals based on health problems, old age, late calving interval and late age at first services with an index value of $0.36,0.26,0.25$, and 0.14 , respectively. For the medium scale producers, dairy cows were culled based on health problem, ate age at first services and late calving interval with an average index value of $0.48,0.33$ and 0.21 , respectively. Unlike to the large and medium scale dairy producers, old age, late calving interval, health problem and difficulty in birth were the main culling criteria for small scale dairy cow producers with an average index value of 0.50 , $0.29,0.26$, and 0.21 , respectively.

Similarly, for crossbreed dairy cattle producers, health problem, old age, late calving interval and late age at first services were the main culling criteria. For the large scale crossbreed dairy cows, health problem (0.45), late age at first services

Table 5. Culling criteria for Holstein Friesian dairy cattle.

\begin{tabular}{|c|c|c|c|c|c|c|c|c|c|c|c|c|c|}
\hline \multirow[b]{2}{*}{ Traits } & \multicolumn{12}{|c|}{ Production system } & \multirow{2}{*}{$\begin{array}{c}\text { Overall } \\
\text { index }\end{array}$} \\
\hline & \multicolumn{4}{|c|}{ Large scale } & \multicolumn{4}{|c|}{ Medium scale } & \multicolumn{4}{|c|}{ Small scale } & \\
\hline Age & $5.00(1)$ & $50.00(10)$ & $40.00(8)$ & 0.26 & 0.00 & 0.00 & 0.00 & 0.00 & $100.00(30)$ & 0.00 & 0.00 & 0.50 & 0.25 \\
\hline LMY & 0.00 & 0.00 & 0.00 & 0.00 & $10.00(4)$ & 0.00 & $7.50(3)$ & 0.06 & 0.00 & 0.00 & 0.00 & 0.00 & 0.02 \\
\hline LAFS & 0.00 & $35.00(7)$ & $15.00(3)$ & 0.14 & 0.00 & $100.00(40)$ & 0.00 & 0.33 & 0.00 & 0.00 & 0.00 & 0.00 & 0.16 \\
\hline $\mathrm{HP}$ & $65.00(13)$ & $5.00(1)$ & $5.00(1)$ & 0.35 & $92.50(37)$ & 0.00 & $7.50(3)$ & 0.48 & $26.67(8)$ & 0.00 & $73.33(22)$ & 0.26 & 0.36 \\
\hline DB & 0.00 & 0.00 & $5.00(1)$ & 0.01 & 0.00 & 0.00 & 0.00 & 0.00 & 0.00 & $26.67(8)$ & $73.33(22)$ & 0.21 & 0.07 \\
\hline LCI & $30.00(6)$ & $10.00(2)$ & $40.00(8)$ & 0.25 & $7.50(3)$ & $10.00(4)$ & $82.50(33)$ & 0.21 & 0.00 & $73.33(22)$ & $26.67(8)$ & 0.29 & 0.25 \\
\hline
\end{tabular}

Note: age $=$ old age, LMY = low milk yield, LAFS = late age at first service, $\mathrm{HP}=$ health problem, $\mathrm{DB}=$ difficulty in birth, $\mathrm{LCI}=$ late calving interval.

Table 6. Culling criteria for crossbreed dairy cattle.

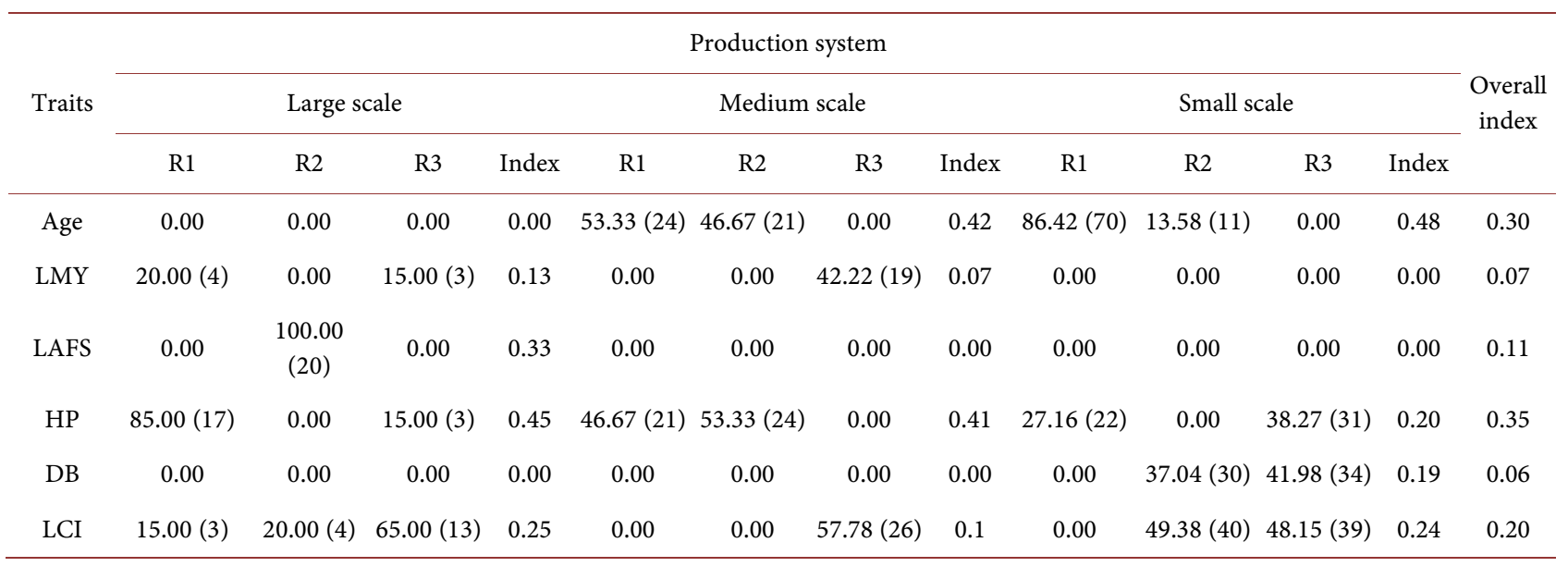

Note: age $=$ old age, $\mathrm{LMY}=$ low milk yield, $\mathrm{LAFS}=$ late age at first service, $\mathrm{HP}=$ health problem, $\mathrm{DB}=$ difficulty in birth, $\mathrm{LCI}=$ late calving interval. 
(0.33), late calving interval (0.25), and low milk yield (0.13) were the main preferred culling criteria. Unlike to the large scale, old age, health problem and low milk yield were the preferred culling criteria for medium scale dairy cows with an average index value of $0.42,0.41$ and 0.07 , respectively. For the small scale crossbreed producers, old age, late calving interval, health problem, and difficulty in birth were the main culling criteria with an average index value of 0.48 , $0.24,0.20$, and 0.19 , respectively. Unlike to the present study, dairy producers in the Alefa and Quara districts of North Gonder zone, Amhara regional state, Ethiopia, were culled their dairy cow based on long age at first service, long calving interval and high number of service per conception with an overall index value of $0.34,0.23$, and 0.20 , respectively [26].

\subsection{Means of Acquiring Dairy Cattle Breeds}

The source of foundation for both Holstein Friesian and crossbreed dairy cows are presented in Table 7. For Holstein Friesian dairy cattle, the sources of establishment herd for most households were purchased, gift from their family, born from their own farm, and from project with an overall percentage value of 43.81, $26.58,17.77$ and 11.9, respectively, whereas for the crossbreed dairy cows the sources of establishment of herds were purchase, followed by developed from AI services, born from own farm, gifted from family and from project with an overall percentage value of $49.95,21.88,15.06,11.44$, and 1.67, respectively (Table 7).

\subsection{Selection Criteria for Holstein Friesian and Crossbreed Dairy Cattle Objective Traits}

The selection criteria both for Holstein Friesian and crossbreed dairy cattle objective traits are presented in Table 8 and Table 9. Identifying and determining selection criteria is a prerequisite for developing a breeding objective. Selection criteria are those traits that can be measured on the animals and can be used as predictors of the traits included in the breeding objectives (Hazel, 1943) [12].

\subsubsection{Milk Composition}

The selection criteria for milk composition both for Holstein Friesian and crossbreed dairy producers are presented in Table 8 and Table 9. For the Holstein Friesian producers, the selection criteria for milk composition were milk yield

Table 7. Means of acquiring Holstein Friesian and crossbreed dairy cattle (\%).

\begin{tabular}{ccccccccc}
\hline \multirow{2}{*}{ Means of acquiring } & \multicolumn{3}{c}{ Holstein Friesian } & \multicolumn{4}{c}{ Crossbreed } \\
\cline { 2 - 8 } & Large scale & Medium scale & Small scale & Overall & Large scale & Medium scale & Small scale & Overall \\
\hline Purchase & $32.50(13)$ & $64.71(55)$ & $34.23(38)$ & 43.81 & $50.00(20)$ & $49.41(42)$ & $50.45(56)$ & 49.95 \\
From project & $15.00(6)$ & $15.29(13)$ & $5.41(2)$ & 11.9 & $5.00(2)$ & 0.00 & 0.00 & 1.67 \\
Born own farm & $22.50(9)$ & 0.00 & $30.63(34)$ & 17.71 & $10.00(4)$ & $11.76(10)$ & $23.42(26)$ & 15.06 \\
Gifted from family & $30.00(12)$ & $20.00(17)$ & $29.73(33)$ & 26.58 & $12.50(5)$ & $4.71(4)$ & $17.12(19)$ & 11.44 \\
From AI services & 0.00 & 0.00 & 0.00 & 0.00 & $22.50(9)$ & $34.12(29)$ & $9.01(10)$ & 21.88 \\
\hline
\end{tabular}


and milk color with an overall index value of 0.61 and 0.39 , respectively. Similar to the Holstein Friesian dairy cattle producers, the selection criteria for milk composition for crossbreed dairy cattle producers, were milk yield and milk color with an overall index value of 0.64 and 0.36 , respectively. In most countries, genetic evaluation of dairy cattle for milk production traits is carried out using test day models [27]. Furthermore, unlike the current study, test day yields of protein, butterfat and lactose are the routinely recorded on milk recorded herds in South African Holstein Friesian and Jersey breeds and therefore are readily available used for as selection criteria [28]. On the other hand, milk colour can also be measured by visual assessment or reflectance colorimetry [29] and milk flavour can be determined by sensory tests which can be considered as selection criteria for milk composition [30].

\subsubsection{Reproductive Traits}

The selection criteria for reproductive traits both for Holstein Friesian and crossbreed dairy cows are presented in Table 8 and Table 9. Reproductive performance has a significant approach to costs related to herd replacement and insemination [31]. In the large and medium scale Holstein Friesian dairy cattle producers, the preferred selection criteria for reproductive traits were age at first calving $(0.42,0.43)$, age at first services $(0.40,0.40)$, and service per conception $(0.13,0.12)$, respectively. Unlike to the large and medium scale, the most preferred selection criteria for small scale Holstein Friesian producers were age at first calving, age at first service and lactation length with an index value of 0.50 , 0.33 and 0.17 , respectively. Similar to Holstein Friesian producers, age at first calving, age at first service and service per conception were the most preferred selection criteria for reproductive traits in the crossbreed dairy cattle producers. In the large scale crossbreed dairy cattle producers, age at first service, age at first calving and service per conception were the most preferred selection criteria for reproductive traits with an index value were $0.43,0.40$ and 0.09 , respectively whereas for medium scale crossbreed dairy cattle producers, age at first calving, service per conception and age at first service were the main selection criteria practiced with a mean index value of $0.45,0.38$ and 0.17 , respectively. Unlike to the medium scale crossbreed dairy cattle producers, age at first service, age at first calving and age at first puberty were the main selection criteria for reproductive traits for small scale crossbreed dairy cattle producers with an index value of, $0.50,0.33$ and 0.17 , respectively. Comparing to the Ethiopian dairy cattle producers, calving ease was considered the main selection criterial for reproductive traits [32]. Unlike the present study, calving interval was considered as selection criteria for the economically relevant traits of reproductive traits for South African Holstein Friesian and Jersey cattle [28].

\subsubsection{Longevity Traits}

The selection criteria for longevity traits both for Holstein Friesian and crossbreed dairy cow are present in Table 5 and Table 6 . In the study sites, the se- 
lection criteria for longevity traits were herd life, number of lactations, and length of productive lifetime and type traits. In the large and small scale Holstein Friesian dairy cattle producers, herd life $(0.44,0.50)$, Length of productive lifetime $(0.39,0.33)$ and number of lactations $(0.17,0.17)$ were the main selection criteria for longevity traits, respectively. Unlike to the large and small scale Holstein Friesian dairy cattle producers, length of productive lifetime, herd life and type traits were the three main selection criteria for medium scale producers with an average index value of $0.42,0.37$, and 0.13 , respectively. Similarly, for the crossbreed respondents, number of lactations, length of productive lifetime and herd life were the main selection criteria for large scale crossbreed dairy producers with an average index value of $0.41,0.37$ and 0.13 , respectively. Similarly for medium scale crossbreed producers, number of lactation (0.39), herd life (0.32), and length of productive lifetime (0.29), respectively, were the main preferred selection criteria for the economically relevant longevity traits. Whereas for small scale crossbreed dairy producers, length of productive lifetime, herd life and number of lactations were the preferred selection criteria with an average index value of $0.44,0.39$, and 0.17 , respectively. Unlike the Ethiopian dairy farms, different countries used a range of selection criteria, models and analytical procedures to predict longevity traits [33]. In the present study even though inclusion of longevity was good progress it needs to be extended to the other major dairy cattle farms as an indispensable task.

\subsubsection{Cow Comfort}

Cow comfort is important in maintaining high production and increasing reproductive success in dairy cows. In the present study farms, the selection criteria for the economically relevant traits of cow comfort wad not widely recorded in medium and small scale both for Holstein Friesian and crossbreed dairy farms. In the large scale Holstein Friesian dairy farms, the selection criteria for cow comfort was, type traits, disease incidence, and somatic cell count with an average index value of $0.43,0.40$ and 0.17 , respectively. Similarly, for the large scale crossbreed dairy producers, type traits, disease incidence and somatic cell counts were the main selection criteria for cow comfort with an index value of $0.48,0.35$, and 0.17, respectively. According to [34], though there was seldom practices of disease recording in most animal recording schemes, incidence of metabolic diseases (e.g. lameness, ketosis, udder oedema, metritis, milk fever and displaced abomasums) were used as a selection criteria to predict economically relevant cow comfort traits. Other studies stated that, dairy form has also been reported to influence involuntary culling, through its relationship with incidence of metabolic diseases [35].

\subsubsection{Udder Health}

Economic performances of farm animals can be losses by diseases, through reduced milk yield, reduced productive life time of animas, reduced genetic gain, and reduced milk quality [36]. The preferred selection criteria for udder health 
traits are present in Table 8 and Table 9. In the study farms, the main selection criteria for udder health traits were incidence of mastitis, somatic cell count and milking speed. In the large scale dairy farms, incidence of mastitis, milking speed and somatic cell count, were the preferred selection criteria for udder health with an average index value of $0.50,0.33$, and 0.17 , respectively. Similarly for medium scale dairy farms, incidence of mastitis, milking speed and somatic cell count were the main selection criteria with an index value of $0.48,0.36$, and 0.17 , respectively. Unlike to the large and medium scale dairy producers, incidence of mastitis (100\%) was the only means of selection criteria for udder health in small scale Holstein Friesian dairy producers. Similar to the Holstein Friesian dairy farms, incidence of mastitis (0.43 and 0.43), milking speed (0.40 and 0.20), and somatic cell count ( 0.17 and 0.37$)$ were the most preferred selection criteria for large and medium scale crossbreed dairy producers. Similar to the small scale Holstein Friesian producers, incidence of mastics (100\%) were the only preferred selection criteria for small scale crossbreed dairy producers. Similar to the current study farms, majority of the Scandinavian countries well-established and undertake routine genetic evaluation for mastitis incidence [37]. According to [38] report, milking speed has a relationship with udder health, with faster milking cows having higher rates of udder infection. Incorporating information on milking speed in breeding program has genetic predictions for udder health traits [39].

\subsubsection{Cow Health}

Ethiopia had not established selection criteria for dairy cattle objectives traits. However, dairy cattle producers used some indicator traits as economically relevant for cow health traits. The selection criteria for the economically relevant traits of cow health both for Holstein Friesian and crossbreed dairy cattle are present in Table 5 and Table 6. In the large scale Holstein Friesian dairy farms, disease incidence, milk yield and type traits were the main selection criteria for cow health with an index value of $0.43,0.29$ and 0.28 , respectively. Unlike to the large scale, milk yield $(0.42,0.44)$, disease incidence $(0.38,0.33)$, and type traits $(0.20,0.23)$, were the most preferred selection criteria for medium and small scale Holstein Friesian dairy producers, respectively. Similarly for large scale crossbreed dairy farms, disease incidence (0.43), milk yield (0.35), and type traits (0.22), were the three preferred selection criteria for cow health, respectively. Whereas for medium and small scale crossbreed producers, milk yield $(0.42,0.40)$, disease incidence $(0.37,0.38)$, and type traits $(0.21,0.22)$, were the most preferred selection criteria for the economically relevant traits of cow health, respectively. according to [40] report, Scandinavian countries have a subsidized and legallyenforced system for recording disease incidence in dairy cattle selection based on such predictions can yield significant genetic progress in disease resistance.

\subsubsection{Feed Cost}

Feed is the most important input requirement for dairy production. In the 
Table 8. Selection criteria for Holstein Friesian dairy cattle objective traits.

\begin{tabular}{|c|c|c|c|c|c|c|c|c|c|c|c|c|c|}
\hline \multirow{3}{*}{ Traits } & \multicolumn{12}{|c|}{ Production system } & \multirow{3}{*}{$\begin{array}{c}\text { Overall } \\
\text { index }\end{array}$} \\
\hline & \multicolumn{4}{|c|}{ Large scale } & \multicolumn{4}{|c|}{ Medium scale } & \multicolumn{4}{|c|}{ Small scale } & \\
\hline & $\mathrm{R} 1$ & R2 & R3 & Index & R1 & $\mathrm{R} 2$ & R3 & Index & $\mathrm{R} 1$ & $\mathrm{R} 2$ & R3 & Index & \\
\hline
\end{tabular}

Milk composition

\begin{tabular}{|c|c|c|c|c|c|c|c|c|c|c|c|c|}
\hline MY & $80.00(16)$ & $20.00(4)$ & - & 0.60 & $\begin{array}{c}90.00 \\
(36)\end{array}$ & $\begin{array}{c}10.00 \\
(4)\end{array}$ & - & 0.63 & $80.00(24)$ & $20.00(6)$ & - & 0.60 \\
\hline MYC & $20.00(4)$ & $\begin{array}{c}80.00 \\
(16)\end{array}$ & - & 0.40 & $\begin{array}{c}10.00 \\
(4)\end{array}$ & $\begin{array}{c}90.00 \\
(36)\end{array}$ & - & 0.37 & $20.00(6)$ & $\begin{array}{c}60.00 \\
(24)\end{array}$ & - & 0.40 \\
\hline
\end{tabular}

Reproductive traits

\begin{tabular}{|c|c|c|c|c|c|c|c|c|c|c|c|c|c|}
\hline HPR & 0.00 & $5.00(1)$ & $5.00(1)$ & 0.03 & 0.00 & 0.00 & 0.00 & 0.00 & 0.00 & 0.00 & 0.00 & 0.00 & 0.01 \\
\hline AFP & 0.00 & 0.00 & $\begin{array}{c}15.00 \\
(3)\end{array}$ & 0.03 & 0.00 & 0.00 & $\begin{array}{c}30.00 \\
(12)\end{array}$ & 0.05 & 0.00 & 0.00 & 0.00 & 0.00 & 0.03 \\
\hline LL & 0.00 & 0.00 & 0.00 & 0.00 & 0.00 & 0.00 & 0.00 & 0.00 & 0.00 & 0.00 & $\begin{array}{c}100.00 \\
(30)\end{array}$ & 0.17 & 0.06 \\
\hline AFS & $40.00(8)$ & $\begin{array}{c}60.00 \\
(12)\end{array}$ & 0.00 & 0.40 & $\begin{array}{c}40.00 \\
(16)\end{array}$ & $\begin{array}{c}60.00 \\
(24)\end{array}$ & 0.00 & 0.40 & 0.00 & $\begin{array}{c}100.00 \\
(30)\end{array}$ & 0.00 & 0.33 & 0.38 \\
\hline SPC & 0.00 & $5.00(1)$ & $\begin{array}{c}70.00 \\
(14)\end{array}$ & 0.13 & 0.00 & 0.00 & $\begin{array}{c}70.00 \\
(28)\end{array}$ & 0.12 & 0.00 & 0.00 & 0.00 & 0.00 & 0.08 \\
\hline $\mathrm{AFC}$ & $60.00(12)$ & $30.00(6)$ & $\begin{array}{c}10.00 \\
(2)\end{array}$ & 0.42 & $\begin{array}{c}60.00 \\
(24)\end{array}$ & $\begin{array}{c}40.00 \\
(16)\end{array}$ & 0.00 & 0.43 & $\begin{array}{c}100.00 \\
(30)\end{array}$ & 0.00 & 0.00 & 0.50 & 0.45 \\
\hline
\end{tabular}

Longevity traits

\begin{tabular}{|c|c|c|c|c|c|c|c|c|c|c|c|c|c|}
\hline $\mathrm{HL}$ & $65.00(13)$ & $35.00(7)$ & 0.00 & 0.44 & 0.00 & $\begin{array}{c}22.50 \\
(9)\end{array}$ & 0.00 & 0.08 & $\begin{array}{c}100.00 \\
(30)\end{array}$ & 0.00 & 0.00 & 0.50 & 0.34 \\
\hline NL & 0.00 & 0.00 & $\begin{array}{c}100.00 \\
(20)\end{array}$ & 0.17 & $\begin{array}{c}22.50 \\
(9)\end{array}$ & $\begin{array}{c}77.50 \\
(31)\end{array}$ & 0.00 & 0.37 & 0.00 & 0.00 & $\begin{array}{c}100.00 \\
(30)\end{array}$ & 0.17 & 0.24 \\
\hline LPLT & $35.00(7)$ & $\begin{array}{c}65.00 \\
(13)\end{array}$ & 0.00 & 0.39 & $\begin{array}{c}77.50 \\
(31)\end{array}$ & 0.00 & $22.50(9)$ & 0.42 & 0.00 & $\begin{array}{c}100.00 \\
(30)\end{array}$ & 0.00 & 0.33 & 0.38 \\
\hline TT & 0.00 & 0.00 & 0.00 & 0.00 & 0.00 & 0.00 & 77.50 & 0.13 & 0.00 & 0.00 & 0.00 & 0.00 & 0.04 \\
\hline
\end{tabular}

Cow comfort

\begin{tabular}{|c|c|c|c|c|}
\hline DI & $40.00(8)$ & $\begin{array}{c}60.00 \\
(12)\end{array}$ & 0.00 & 0.40 \\
\hline SCC & 0.00 & 0.00 & $\begin{array}{c}100.00 \\
(20\end{array}$ & 0.17 \\
\hline TT & $60.00(12)$ & $40.00(8)$ & 0.00 & 0.43 \\
\hline
\end{tabular}

Udder health

$\begin{array}{cccccccccccccc}\text { IM } & 100.00(20) & 0.00 & 0.00 & 0.50 & \begin{array}{c}80.00 \\ (32)\end{array} & \begin{array}{c}20.00 \\ (8)\end{array} & 0.00 & 0.47 & \begin{array}{c}100.00 \\ (30)\end{array} & - & - & 1.00 \\ \text { SCC } & 0.00 & 0.00 & \begin{array}{c}100.00 \\ (20)\end{array} & 0.17 & 0.00 & 0.00 & \begin{array}{c}100.00 \\ (40)\end{array} & 0.17 & - & - & - \\ & & & & & & & & \\ \text { MS } & 0.00 & \begin{array}{c}100.00 \\ (20)\end{array} & 0.00 & 0.33 & \begin{array}{c}20.00 \\ (8)\end{array} & \begin{array}{c}80.00 \\ (32)\end{array} & 0.00 & 0.36 & - & - & - & - \\ \end{array}$




\section{Continued}

Cow health

\begin{tabular}{|c|c|c|c|c|c|c|c|c|c|c|c|c|}
\hline DI & $55.00(11)$ & $45.00(9)$ & 0.00 & 0.43 & $\begin{array}{c}40.00 \\
(16)\end{array}$ & $\begin{array}{c}50.00 \\
(20)\end{array}$ & $10.00(4)$ & 0.38 & $20.00(6)$ & $\begin{array}{c}60.00 \\
(18)\end{array}$ & $20.00(6)$ & 0.33 \\
\hline TT & $20.00(4)$ & $30.00(6)$ & $\begin{array}{c}50.00 \\
(10)\end{array}$ & 0.28 & $\begin{array}{c}5.00 \\
(2)\end{array}$ & $\begin{array}{c}12.50 \\
(5)\end{array}$ & $\begin{array}{c}82.50 \\
(33)\end{array}$ & 0.20 & $6.67(2)$ & $23.33(7)$ & $\begin{array}{c}70.00 \\
(21)\end{array}$ & 0.23 \\
\hline MY & $25.00(5)$ & $25.00(5)$ & $\begin{array}{c}50.00 \\
(10)\end{array}$ & 0.29 & $\begin{array}{c}57.50 \\
(23)\end{array}$ & $\begin{array}{c}35.00 \\
(14)\end{array}$ & $7.50(3)$ & 0.42 & $73.33(22)$ & $16.67(5)$ & $10.00(3)$ & .44 \\
\hline
\end{tabular}

Feed cost

$\begin{array}{ccccc}\begin{array}{c}\text { Body } \\ \text { weight }\end{array} & 60.00(12) & 40.00(8) & - & 0.53 \\ \text { Feed intake } & 40.00(8) & \begin{array}{c}60.00 \\ (12)\end{array} & - & 0.47\end{array}$

Note: $\mathrm{MY}=$ milk yield, $\mathrm{MYC}=$ milk yield composition, $\mathrm{HPR}=$ heifers pregnancy rate, $\mathrm{AFP}=$ age at first puberty, LL $=$ lactation length, AFS $=$ age at first service, $\mathrm{SPC}=$ service per conception, $\mathrm{AFC}=$ age at first calving, $\mathrm{HL}=$ herd life, $\mathrm{NL}=$ number of lactations, $\mathrm{LPLT}=$ length of productive life time, $\mathrm{TT}=$ type traits, DI = disease incidence, $\mathrm{SCC}=$ somatic cell count, $\mathrm{IM}=$ incidence of mastitis, $\mathrm{MS}=$ milking speed.

Table 9. Selection criteria for crossbreed dairy cattle objective traits.

\begin{tabular}{|c|c|c|c|c|c|c|c|c|c|c|c|c|c|}
\hline \multirow{3}{*}{ Traits } & \multicolumn{12}{|c|}{ Production system } & \multirow{3}{*}{$\begin{array}{c}\text { Overall } \\
\text { index }\end{array}$} \\
\hline & \multicolumn{4}{|c|}{ Large scale } & \multicolumn{4}{|c|}{ Medium scale } & \multicolumn{4}{|c|}{ Small scale } & \\
\hline & $\mathrm{R} 1$ & $\mathrm{R} 2$ & R3 & Index & $\mathrm{R} 1$ & $\mathrm{R} 2$ & R3 & Index & $\mathrm{R} 1$ & $\mathrm{R} 2$ & R3 & Index & \\
\hline \multicolumn{14}{|c|}{ Milk composition } \\
\hline MY & $\begin{array}{c}90.00 \\
(18)\end{array}$ & $\begin{array}{c}10.00 \\
(2)\end{array}$ & 0.00 & 0.63 & $95.56(43)$ & $\begin{array}{l}4.44 \\
(2)\end{array}$ & 0.00 & 0.65 & $\begin{array}{c}91.36 \\
(74)\end{array}$ & $8.64(7)$ & 0.00 & 0.64 & 0.64 \\
\hline MYC & $\begin{array}{c}10.00 \\
(2)\end{array}$ & $\begin{array}{c}90.00 \\
(18)\end{array}$ & 0.00 & 0.37 & $4.44(2)$ & $\begin{array}{c}95.56 \\
(43)\end{array}$ & 0.00 & 0.35 & $8.64(7)$ & $\begin{array}{c}91.36 \\
(74)\end{array}$ & 0.00 & 0.36 & 0.36 \\
\hline \multicolumn{14}{|c|}{ Reproductive traits } \\
\hline AFP & 0.00 & 0.00 & $45.00(9)$ & 0.08 & 0.00 & 0.00 & 0.00 & 0.00 & 0.00 & 0.00 & $\begin{array}{c}100.00 \\
(81)\end{array}$ & 0.17 & 0.08 \\
\hline AFS & $\begin{array}{c}60.00 \\
(12)\end{array}$ & $\begin{array}{c}40.00 \\
(8)\end{array}$ & 0.00 & 0.43 & 0.00 & 0.00 & $\begin{array}{c}100.00 \\
(45)\end{array}$ & 0.17 & $\begin{array}{c}100.00 \\
(81)\end{array}$ & 0.00 & 0.00 & 0.50 & 0.37 \\
\hline SPC & 0.00 & 0.00 & $\begin{array}{c}55.00 \\
(11)\end{array}$ & 0.09 & $26.67(12)$ & $\begin{array}{c}73.33 \\
(33)\end{array}$ & 0.00 & 0.38 & 0.00 & 0.00 & 0.00 & 0.00 & 0.17 \\
\hline $\mathrm{AFC}$ & $\begin{array}{c}40.00 \\
(8)\end{array}$ & $\begin{array}{c}60.00 \\
(12)\end{array}$ & 0.00 & 0.40 & $73.33(33)$ & $\begin{array}{c}26.67 \\
(12)\end{array}$ & 0.00 & 0.45 & 0.00 & $\begin{array}{c}100.00 \\
(81)\end{array}$ & 0.00 & 0.33 & 0.39 \\
\hline \multicolumn{14}{|c|}{ Longevity traits } \\
\hline HL & 0.00 & $\begin{array}{c}35.00 \\
(7)\end{array}$ & $10.00(2)$ & 0.13 & $46.67(21)$ & 0.00 & $\begin{array}{c}53.33 \\
(24)\end{array}$ & 0.32 & $\begin{array}{c}34.57 \\
(28)\end{array}$ & $\begin{array}{c}65.43 \\
(53)\end{array}$ & 0.00 & 0.39 & 0.28 \\
\hline $\mathrm{NL}$ & $\begin{array}{c}45.00 \\
(9)\end{array}$ & $\begin{array}{c}55.00 \\
(11)\end{array}$ & 0.00 & 0.41 & $35.56(16)$ & $\begin{array}{c}64.44 \\
(29)\end{array}$ & 0.00 & 0.39 & 0.00 & 0.00 & $\begin{array}{c}100.00 \\
(81)\end{array}$ & 0.17 & 0.32 \\
\hline LPLT & $\begin{array}{c}55.00 \\
(11)\end{array}$ & $\begin{array}{c}10.00 \\
(2)\end{array}$ & $35.00(7)$ & 0.37 & $17.78(8)$ & $\begin{array}{c}35.56 \\
(16)\end{array}$ & $\begin{array}{c}46.67 \\
(21)\end{array}$ & 0.29 & $\begin{array}{c}65.43 \\
(53)\end{array}$ & $\begin{array}{c}34.57 \\
(28)\end{array}$ & 0.00 & 0.44 & 0.37 \\
\hline $\mathrm{TT}$ & 0.00 & 0.00 & $\begin{array}{c}55.00 \\
(11)\end{array}$ & 0.09 & 0.00 & 0.00 & 0.00 & 0.00 & 0.00 & 0.00 & 0.00 & 0.00 & 0.03 \\
\hline
\end{tabular}




\section{Continued}

$\begin{array}{ccccc}\text { Cow comfort } & & & & \\ \text { DI } & \begin{array}{c}10.00 \\ (2)\end{array} & \begin{array}{c}90.00 \\ (18)\end{array} & 0.00 & 0.35 \\ \text { SCC } & 0.00 & 0.00 & \begin{array}{c}100.00 \\ (20)\end{array} & 0.17 \\ & 90.00 & 10.00 & 0.00 & 0.48 \\ \text { TT } & (18) & (2) & & \end{array}$

Udder health

\begin{tabular}{|c|c|c|c|c|c|c|c|c|c|c|c|}
\hline IM & $\begin{array}{c}60.00 \\
(12)\end{array}$ & $\begin{array}{c}40.00 \\
(8)\end{array}$ & 0.00 & 0.43 & $71.11(32)$ & $\begin{array}{c}17.78 \\
(8)\end{array}$ & $\begin{array}{c}11.11 \\
(5)\end{array}$ & 0.43 & $\begin{array}{c}100.00 \\
(81)\end{array}$ & - & - \\
\hline SCC & 0.00 & 0.00 & $\begin{array}{c}100.00 \\
(20)\end{array}$ & 0.17 & $20.00(9)$ & $\begin{array}{c}80.00 \\
(36)\end{array}$ & 0.00 & 0.37 & 0.00 & - & - \\
\hline MS & $\begin{array}{c}40.00 \\
(8)\end{array}$ & $\begin{array}{c}60.00 \\
(12)\end{array}$ & 0.00 & 0.40 & $8.89(4)$ & $\begin{array}{c}6.67 \\
(3)\end{array}$ & $\begin{array}{c}84.44 \\
(38)\end{array}$ & 0.20 & - & - & - \\
\hline
\end{tabular}

Cow health

\begin{tabular}{|c|c|c|c|c|c|c|c|c|c|c|c|c|}
\hline DI & $\begin{array}{c}60.00 \\
(12)\end{array}$ & $\begin{array}{c}35.00 \\
(7)\end{array}$ & $5.00(1)$ & 0.43 & $28.89(13)$ & $\begin{array}{c}64.44 \\
(29)\end{array}$ & $6.67(3)$ & 0.37 & $\begin{array}{c}53.09 \\
(43)\end{array}$ & $\begin{array}{c}23.46 \\
(19)\end{array}$ & $\begin{array}{c}23.46 \\
(19)\end{array}$ & 0.38 \\
\hline TT & $\begin{array}{c}15.00 \\
(3)\end{array}$ & 0.00 & $\begin{array}{c}85.00 \\
(17)\end{array}$ & 0.22 & $4.44(2)$ & $\begin{array}{c}17.78 \\
(8)\end{array}$ & $\begin{array}{c}77.78 \\
(35)\end{array}$ & 0.21 & 0.00 & $\begin{array}{c}30.86 \\
(25)\end{array}$ & $\begin{array}{c}69.14 \\
(56)\end{array}$ & 0.22 \\
\hline MY & $\begin{array}{c}25.00 \\
(5)\end{array}$ & $\begin{array}{c}65.00 \\
(13)\end{array}$ & $10.00(2)$ & 0.35 & $66.67(30)$ & $\begin{array}{c}17.78 \\
(8)\end{array}$ & $\begin{array}{c}15.65 \\
(7)\end{array}$ & 0.42 & $\begin{array}{c}46.91 \\
(38)\end{array}$ & $\begin{array}{c}45.68 \\
(37)\end{array}$ & $7.41(6)$ & 0.40 \\
\hline
\end{tabular}

Feed cost

$\begin{array}{ccccc}\text { Body weight } & \begin{array}{c}70.00 \\ (14)\end{array} & \begin{array}{c}30.00 \\ (6)\end{array} & - & 0.57 \\ & & & & \\ \text { Feed intake } & 30.00 & 70.00 & - & 0.43 \\ & (6) & (14) & & \end{array}$

Note: $\mathrm{MY}=$ milk yield, $\mathrm{MYC}=$ milk yield composition, $\mathrm{AFP}=$ age at first puberty, $\mathrm{LL}=$ lactation length, $\mathrm{AFS}=$ age at first service, $\mathrm{SPC}=$ service per conception, $\mathrm{AFC}=$ age at first calving, $\mathrm{HL}=$ herd life, $\mathrm{NL}=$ number of lactations, $\mathrm{LPLT}=$ length of productive life time, $\mathrm{TT}=$ type traits, $\mathrm{DI}=$ disease incidence, $\mathrm{SCC}=$ somatic cell count, $\mathrm{IM}=$ incidence of mastitis, $\mathrm{MS}=$ milking speed.

present study, both medium and small scale Holstein Friesian and crossbreed dairy farms, didn't have any criteria for predicting the economically relevant trait of feed for their dairy cows. Whereas in the large scale Holstein Friesian and crossbreed dairy cattle producers, body weight $(0.57,0.53)$, and feed intake $(0.43$, 0.43 ), were the most preferred selection criteria for the economically relevant traits feed cost, respectively. Unlike the current study, body weight, milk urea nitrogen, stature, rump length and width, body depth and feed intake are most practiced selection criteria for the economical trait of feed cost for South African Holstein Friesian and Jersey cattle breeds [27]. So, Integrating multi-traits is important to improve the genetic merit for efficiency of feed utilization.

\section{Conclusions and Recommendations}

The present study focuses on the selection criteria of dairy cattle objective traits. The contribution of the livestock sector to the Ethiopian economy is manifold. It 
provide the needed animal protein in the form of products like meat, milk, eggs and cheese contributing to nutritional security; provide power for cultivation, threshing, and transport; confer a certain degree of security during periods of crop failure; provide farmyard manure to improve soil fertility and also as a source of energy; and other economic and social benefits. In the present study, dairy farm producers did not had standardized criteria for their dairy cattle objective traits particularly in the medium and small scale farms both for Holstein Friesian and crossbreed producers they did not fix any criteria for cow comfort, feed cost and udder health (in small scale dairy farms) dairy cattle objective traits. So, to improve the existing dairy cattle production potential giving equal opportunities for all dairy cattle objective traits and setting selection criteria for each of the dairy cow trait is an indispensable task.

\section{Acknowledgements}

The authors gratefully acknowledge Haramaya University and Ethiopian Institute of Agricultural Research (EIAR), and Holeta agricultural research institution for funding and backing this research work. All dairy farm owners, all experts and development agents in Bishoftu, Holeta, Mekele, Harar and Dire-Dawa who participated in this study are highly acknowledged.

\section{Conflict of Interests}

The authors declare no conflicts of interest regarding the publication of this paper.

\section{References}

[1] CSA (Central Statistical Agency) (2016) Federal Democratic Republic of Ethiopia Central Statistical Agency, Agricultural Sample Survey Report on Livestock and Livestock Characteristics (Private Peasant Holdings).Volume II, Addis Ababa.

[2] FAO (Food and Agriculture Organization of the United Nations) (2010) Breeding Strategies for Sustainable Management of Animal Genetic Resources. Food and Agriculture Organization, Rome, FAO Animal Production and Health Guidelines Number 3, XVII-122.

[3] Kumar, N. and Tkui, K. (2014) Reproductive Performance of Crossbred Dairy Cows in Mekelle, Ethiopia. Journal of Animal Science, 3, 35-40.

[4] Lobago, F., Bekana, M., Gustafsson, H. and Kindahl, H. (2007) Longitudinal Observation on Reproductive and Lactation Performances of Smallholder Crossbred Dairy Cattle in Fitche, Oromia Region, Central Ethiopia. Tropical Animal Health and Production, 39, 395-403. https://doi.org/10.1007/s11250-007-9027-z

[5] Groen Ab, F., Steine, T., Colleau, J.-J., Pedersen, J., Priby, J. and Reinsch, N. (1997) Economic Values in Dairy Cattle Breeding, with Special Reference to Functional Traits. Report of an EAAP-Working Group. Livestock Production Science, 49, 1-21. https://doi.org/10.1016/S0301-6226(97)00041-9

[6] Godadaw, M., Zewdu, W. and Workneh, A. (2014) Breeding Practices in Indigenous Dairy Cattle Breeds in Northern Amhara, Ethiopia. Livestock Research for Rural Development, 26, Article 62. http://www.lrrd.org/lrrd26/4/misg26062.htm 
[7] Brumatti, R.C., Ferraz, J.B.S., Eler, J.P. and Formigonni, I.B. (2011) Desenvolvimento de índice de seleção em gado de corte sobo enfoque de um modelo bioeconômico. Archivos de Zootecnia, 60, 205-213.

https://doi.org/10.4321/S0004-05922011000200005

[8] Bittencourt, T.C.C., Lôbo, R.B. and Bezerra, L.A.F. (2006) Objetivos de seleção para sistemas de produção de gado de corteem pasto: Ponderadores econômicos. Arquivo Brasileiro de Medicina Veterinária e Zootecnia, 58, 196-204. https://doi.org/10.1590/S0102-09352006000200008

[9] Laske, C.H., Teixeira, B.B.M., Dionello, N.J.L. and Cardoso, F.F. (2012) Breeding Objectives and Economic Values for Traits of Low Input Family-Based Beef Cattle Production System in the State of Rio Grande do Sul. Revista Brasileira de Zootecnia, 41, 298-305. https://doi.org/10.1590/S1516-35982012000200010

[10] Pravia, M.I., Ravagnolo, O., Urioste, J.I. and Garrick, D.J. (2014) Identification of Breeding Objectives Using a Bioeconomic Model for a Beef Cattle Production System in Uruguay. Livestock Science, 160, 21-28. https://doi.org/10.1016/j.livsci.2013.12.006

[11] Jorge Júnior, J., Cardoso, V.L. and Albuquerque, L.G. (2007) Objetivos de seleção e valores econômicos em sistemas de produção de gado de corte no Brasil. Revista Brasileira de Zootecnia, 36, 1549-1558. https://doi.org/10.1590/S1516-35982007000700013

[12] Hazel, L.N. (1943) Genetic Basis for Constructing Selection Indexes. Genetics, 28, 476-490.

[13] Golden, B.L., Garrick, D.J., Newman, S. and Enns, R.M. (2000) Economically Relevant Traits: A Framework for the Next Generation of EPDs. 32nd Annual Research Symposium and Annual Meeting, Beef Improvement Federation, Wichita, 2-13.

[14] Schneeberger, M., Barwick, S.A., Crow, G.H. and Hammond, K. (1992) Economic Indices Using Breeding Values Predicted by BLUP. Journal of Animal Breeding and Genetics, 109, 180-187. https://doi.org/10.1111/j.1439-0388.1992.tb00395.x

[15] Woolliams, J.A. and Smith, C. (1988) Value of Indicator Traits in the Genetic Improvement of Dairy Cattle. Animal Production, 46, 333-345. https://doi.org/10.1017/S0003356100018948

[16] Melese, B. and Dutamo, Z. (2015) Statistical Analysis of Road Traffic Car Accident in Dire Dawa Administrative City, Eastern Ethiopia. Science Journal of Applied Mathematics and Statistics, 3, 250-256. https://doi.org/10.11648/j.sjams.20150306.14

[17] Mumed, A. and Eshetu, A. (2015) A Cross Sectional Study on Prevalence of Cephalopina Titillate or Infection in Camel (Camelus Dromedaries) in Dire Dawa Administrative Region, Ethiopia. Advances in Biological Research, 9, 225-229.

[18] CSA (Central Statistical Agency) (2013) Population Projection of Ethiopia for the Year 2014. Federal Democratic Republic of Ethiopia, Central Statistical Agency, Addis Ababa, 4-38.

[19] Ketema, M., Aman, M., Seifu, E., Getachew, T., Hawaz, E. and Hailu, Y. (2016) The Dairy Value Chain and Factors Affecting Choice of Milk Channels in Harar and Dire Dawa Areas, Eastern Ethiopia. Review of Agricultural and Applied Economics, 19, 1-9. https://doi.org/10.15414/raae.2016.19.02.10-18

[20] Bereda, A., Yilma, Z. and Nurfeta, A. (2014) Dairy Production System and Constraints in Ezha Districts of the Gurage Zone, Southern Ethiopia. Global Veterinarian, 12, 181-186.

[21] IPMS (Improving Productivity and Market Success) (2005) Ethiopian Farmers 
Project. Working Paper 9, ILRI (International Livestock Research Institute), Nairobi, 62.

[22] Tigray Regional Office (2010) Mekelle Town Information. Mekelle.

[23] CSA (Central Statistical Agency) (2007) Population Dynamics. Central Statistical Agency, Addis Ababa.

[24] SAS (Statistical Analysis System) (2008) SAS for Windows, Release 9.2. User's Guide. SAS Institute, Inc., Cary.

[25] Duguma, B. and Janssens, G.P.J. (2016) Smallholder Dairy Farmers' Breed and Cow Trait Preferences and Production Objective in Jimma Town, Ethiopia. European Journal of Biological Sciences, 8, 26-34.

[26] Ayeneshet, B., Wondifraw, Z. and Abera, M. (2017) Production Objectives, Breeding Practices and Rate of Inbreeding in Dairy Cows at Alefa and Quara Districts of North Gondar Zone, Amhara National Regional State, Ethiopia. International Journal of Animal Science, 1, 1011.

[27] Interbull (2009) Routine Genetic Evaluation for Production Traits. http://www.interbull.org/eval/framesida-prod.htm

[28] Banga, C.B. (2009) The Development of Breeding Objectives for Holstein and Jersey Cattle in South Africa. Thesis, the Faculty of Natural and Agricultural Sciences, Department of Animal, Wildlife and Grassland Sciences, University of the Free State, Bloemfontein.

[29] Kneifel, W., Ulberth, F. and Schaffer, E. (1992) Tristimulus Colour Reflectance Measurement of Milk and Dairy Products. Le Lait, 72, 383-391.

https://doi.org/10.1051/lait:1992427

[30] Baldwin, R.E., Shelley, D.S. and Marshall, R.T. (1982) Flavour of Milk One Week after Addition of Iron Complex. Journal of Dairy Science, 65, 1390-1393. https://doi.org/10.3168/jds.S0022-0302(82)82359-X

[31] French, P.D. and Nebel, R.L. (2003) Simulated Economic Cost of Extended Calving Intervals in Dairy Herds and Comparison of Reproductive Management Programs. Journal of Dairy Science, 86, 54.

[32] Wiggans, G.R., Misztal, I. and Van Tassell, C.P. (2003) Calving Ease (Co)variance Components for a Sire-Maternal Grandsire Threshold Model. Journal of Dairy Science, 86, 1845-1848. https://doi.org/10.3168/jds.S0022-0302(03)73771-0

[33] Van der Linde, C. and de Jong, G. (2003) Mace for Longevity Traits. Interbull Bulletin, No. 30, 3-9.

[34] ICAR (2012) International Committee for Animal Recording Guidelines for Recording, Evaluation and Genetic Improvement of Health Traits. http://www.icar.org

[35] Lassen, J., Hansen, M., Sorensen, M.K., Aamand, G.P., Christensen, L.G. and Madsen, P. (2003) Genetic Relationship between Body Condition Score, Dairy Character, Mastitis, and Diseases Other than Mastitis in First-Parity Danish Holstein Cows. Journal of Dairy Science, 86, 3730-3735. https://doi.org/10.3168/jds.S0022-0302(03)73979-4

[36] Shook, G.E. (1989) Selection for Disease Resistance. Journal of Dairy Science, 72, 1349. https://doi.org/10.3168/jds.S0022-0302(89)79242-0

[37] Heringstad, B., Klemetsdal, G. and Ruane, J. (2000) Selection for Mastitis Resistance in Dairy Cattle: A Review with Focus on the Situation in the Nordic Countries. $\mathrm{Li}$ vestock Production Science, 64, 94-106. https://doi.org/10.1016/S0301-6226(99)00128-1

[38] Zwald, N.R., Weigel, K.A., Chang, Y.M., Welper, R.D. and Clay, J.S. (2005) Genetic 
Evaluation of Dairy Sires for Milking Duration Using Electronically Recorded Milking Times of Their Daughters. Journal of Dairy Science, 88, 1192-1198. https://doi.org/10.3168/jds.S0022-0302(05)72785-5

[39] Miglior, F., Muir, B.L. and Van Doormaal, B.J. (2005) Selection Indices in Holstein Cattle of Various Countries. Journal of Dairy Science, 88, 1255-1263.

https://doi.org/10.3168/jds.S0022-0302(05)72792-2

[40] Heringstad, B., Klemetsdal, G. and Steine, T. (2007) Selection Responses for Disease Resistance in Two Selection Experiments with Norwegian Red Cows. Journal of Dairy Science, 90, 2419-2426. https://doi.org/10.3168/jds.2006-805 


\section{Appendix}

\section{Questionnaire}

\section{General information}

1.1. Name of respondent age

Region zone

Gender

1.2. Position in household (tick one)
A. household head
B. spouse head
C. relative
D. son
E. daughter
F. other (specify)

1.3. Marital status (tick one)
A. Married
B. Divorced
C. Widowed
D. Unmarried
E. Other (specify)

\section{Household characteristics}

A. How many children between age 10 and 18 years are in this household?

B. How many children less than 10 years old are in this household?

C. How many children above 18 years old are in this household?

D. Total number of children in this household?

E. How many dairy laborers are in this household?

F. How many permanent workers in this household?

\section{Land owner and its allocation for farm activities}

A. Do you own/rent/squatter/gifted land (tick one)?

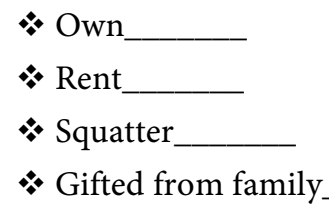

B. How many hectare of land do you have?

C. How many plots of land do own?

- Amount of land used to cultivate for crop (in hectare)

* Amount of land used to cultivate for improve forage (in hectare)

* Amount of land used to grazing land (in hectare)

- Amount of land used for conserved hay production(in hectare)

* Types of improved forage crops cultivated? (Tick)

$\begin{array}{lll}\text { Oat__ Vetch__ Elephant grass_ } & \text { Others (specify) } \\ \text { Legume trees } & & \text { Othen }\end{array}$

\section{Herd structure of household}

A. What type of cattle breed (s) do you have? (Tick and number)

* Pure exotic only

* Crossbreed only

Local only

Both pure exotic and crossbreed 
Both crossbreed and local

Both pure exotic and local

* All

B. What other livestock species do you have? (Tick and number)

* Horses

Donkey

Mule

- Chicken

Sheep

Goats

Honey bee

- Camel

C. How many pure exotic cattle do you have? (Tick and number)

Milking cows

Dry cows

* Oxen

- Heifers greater than one year pregnant

* Heifers greater than one year non-pregnant

* Calves less than one year

D. Which exotic cattle breed do you have? (Tick and number)

* Holstein Friesian

* Jersey

* I do not know

* Others (specify)

E. How many crossbreed cattle do you have? (Tick and number)

Milking cows

Dry cows

Oxen

Heifers greater than one year pregnant

Heifers greater than one year non-pregnant

- Calves less than one year

F. Do you know the type of crossbreed animal you owned? Yes / no. if yes which crossbreed type?

- Holstein Friesian crossbreed

- Jersey crossbreed

* Others (specify)

G. How many local cattle do you have?

- Milking cows

Dry cows

Oxen

Heifers greater than one year pregnant

Heifers greater than one year non-pregnant

* Calves less than one year 
H. How do you first acquire pure exotic dairy cattle? Tick.

* Purchase

* From project

* Born from own farm

* Inherited from family

* Others (specify)

I. How do you first acquire crossbred dairy cattle? Tick.

* Purchase

From project

Born from own farm

* Inherited from family

* Others (specify)

J. How do you first acquire local dairy cattle? Tick.

Purchase

From project

Born from own farm

Inherited from family

Others (specify)

\section{Breed preferences for pure exotic, crossbreed and local dairy cattle}

A. Which breed do prefer first (breed rank first).

* Pure Holstein Friesian

* Pure jersey breed

* Holstein Friesian crosses

* Jersey crosses

* Local breeds

B. What are the reasons to rank first (multiple choice is possible)? Tick.

* High milk production

* Large body size

* High feed conversion efficiency

* Butter yield

* High reproductive efficiency

* High disease resistance

* Fast growth rate

* Dairy type

* Good longevity

* Temperament

* I do not know

* Others (specify)

C. Which breed do prefer second (breed rank second).

* Pure Holstein Friesian

* Pure jersey breed

* Holstein Friesian crosses

* Jersey crosses 
Local breeds

D. What are the reasons to rank second (multiple choices are possible)? Tick.

* High milk production

* Large body size

* High feed conversion efficiency

* Butter yield

* High reproductive efficiency

* High disease resistance

* Fast growth rate

* Dairy type

* Good longevity

* Temperament

* I do not know

* Others (specify)

E. Which breed do prefer third (breed rank third).

* Pure Holstein Friesian

* Pure jersey breed

* Holstein Friesian crosses

* Jersey crosses

* Local breeds

F. What are the reasons to rank third (multiple choice is possible)? Tick.

* High milk production

* Large body size

* High feed conversion efficiency

* Butter yield

* High reproductive efficiency

* High disease resistance

* Fast growth rate

* Dairy type

* Good longevity

* Temperament

* I do not know

* Others (specify)

\section{Breed choice for crossbreeding}

A. Which breed type do you prefer to crossbreed your cows? Tick one.

* Holstein Friesian

* Jersey

* Crossbreed

* I do not know

* Chosen by inseminators

* Others (specify)

B. If you prefer to use Holstein Friesian sire, explain why? Multiple choices possible. 
For high milk production

* Large body size

* Butter yield

* Temperament

* Feed conversion efficiency

* Better reproductive efficiency

* Fast growth rate

* Easy to breed

* Disease resistance

* Udder conformation

* I do not know

* Other (specify)

C. If you prefer to crossbreed your cows with Holstein Friesian sir, what level of exotic inheritance do you prefer? Tick.

* $25 \%$

* $37.5 \%$

* $50 \%$

* $75 \%$

$>75 \%$

* I do not know

* Other (specify)

D. If you prefer to use jersey sire, explain why? Multiple choices possible.

* For high milk production

* Large body size

* Butter yield

* Temperament

* Feed conversion efficiency

* Better reproductive efficiency

* Fast growth rate

* Easy to breed

* Disease resistance

* Udder conformation

* I do not know

* Other (specify)

E. If you prefer to crossbreed your cows with jersey sir, what level of exotic inheritance do you prefer? Tick

$25 \%$
$* 37.5 \%$
* $50 \%$
$* 75 \%$
$* 75 \%$
$*$ I do not know
$*$ Other (specify)

\section{Reproductive efficiency}


A. For pure Holstein Friesian dairy cattle

* Estimate age at first calving (in days/months)

* Estimate age at first service (in days/months)

* Estimate day open (from calving to the next insemination/service) (in months)

* Estimate number of lactations completed(months/ days)

B. For Holstein Friesian cross local dairy cattle

* Estimate age at first calving (in days/months)

* Estimate age at first service (in days/months)

* Estimate day open(from calving to the next insemination/service) (in months)

* Estimate number of lactations completed(months/ days)

C. For pure jersey dairy cattle

* Estimate age at first calving (in days/months)

* Estimate age at first service (in days/months)

* Estimate day open(from calving to the next insemination/service) (in months)

* Estimate number of lactations completed(months/ days)

* For jersey cross local dairy cows

* Estimate age at first calving (in days/months)

* Estimate age at first service (in days/months)

* Estimate day open(from calving to the next insemination/service) (in months)

* Estimate number of lactations completed(months/ days)

D. For local dairy cows

* Estimate age at first calving (in days/months)

* Estimate age at first service (in days/months)

* Estimate day open(from calving to the next insemination/service) (in months)

* Estimate number of lactations completed(months/ days)

\section{Milk production}

A. For Holstein Friesian dairy cattle if any

* What is the average daily milk yield in liters from calving to the first three months (early lactation stage) (in liters)?

* What is the average daily milk yield in liters during mid-lactation (from 3 - 6 months) (in liters)?

* What is the average daily milk yield in liters during late lactation (from 6 months onwards) (in liters)?

B. For pure jersey dairy cattle if any

* What is the average daily milk yield in liters from calving to the first three months (early lactation stage) (in liters)?

* What is the average daily milk yield in liters during mid lactation (from 3 - 6 months) (in liters)? 
What is the average daily milk yield in liters during late lactation (from 6 months onwards) (in liters)?

C. For Holstein Friesian cross local dairy cattle

* What is the average daily milk yield in liters from calving to the first three months (early lactation stage) (in liters)?

* What is the average daily milk yield in liters during mid lactation (from 3 - 6 months) (in liters)?

* What is the average daily milk yield in liters during late lactation (from 6 months onwards) (in liters)?

D. For jersey cross local dairy cattle if any

* What is the average daily milk yield in liters from calving to the first three months (early lactation stage) (in liters)?

* What is the average daily milk yield in liters during mid lactation (from 3 - 6 months) (in liters)?

* What is the average daily milk yield in liters during late lactation (from 6 months onwards) (in liters)?

\section{Major farming activates practiced by the household}

A. What is the major farming activity/ practiced? Tick box

* Livestock production only

* Crop production only

* Both

B. What is the main purpose of keeping pure exotic cattle?

* Only for milk production

* To produce replacement heifers

* To produce replacement draught oxen

* Mainly to produce replacement draught oxen followed by milk

* Indicators of wealth status in the community

* Others (specify)

C. What is the main purpose of keeping crossbreed cattle?

* Only for milk production

* Mainly to produce milk followed by replacement heifers

* Mainly to produce milk followed by draught oxen

* Mainly to produce replacement draught oxen followed by milk

* Indicators of wealth status in the community

* Others (specify)

D. What is the main purpose of keeping local cattle?

Only for milk production

Mainly to produce milk followed by replacement heifers

* Mainly to produce milk followed by draught oxen

* Mainly to produce replacement draught oxen followed by milk

* Indicators of wealth status in the community

* Others (specify) 


\section{Dairy cattle trait preferences}

A. Which of the dairy traits/conformation your prefer most in your dairy farm? Milk traits

Milk persistency

* Age at first calving

* Lactation length

* Fat yield

* Butter yield

\section{Input costs and output costs}

A. Breeding costs

What is your preferred breeding method?

Artificial insemination(AI)

* Bull service/natural mating

B. If your preference is artificial insemination, who provide the service?

* Government

* Private AI services

* Both

C. If the service is given by government, what is cost per insemination (ETB)

D. If the service is given private AI service, what is cost per insemination (ETB)

E. If the service is by bull service what is cost per bull service(ETB)

\section{Feed costs}

A. Do you use concentrate? yes/no (tick one)

If yes, price per quintal in ETB in2014?

If yes, price per quintal in ETB in2015?

$>$ If yes, price per quintal in ETB in2016?

If yes, price per quintal in ETB in2017?

B. Do you buy hay? Yes/no (tick one)

What is the unit?

Bell

- Heap

* Land size(convert to hectare)

What is the price per unit per the unit selected above in 2014?

What is the price per unit per the unit selected above in 2015?

What is the price per unit per the unit selected above in 2016?

What is the price per unit per the unit selected above in 2017?

13. What is the source of costs for your dairy farm? 
14. What is the source of income for your dairy farm?

15. What is your breeding goal?

16. How do you define your goal/profit in your production system? (Rank)
A. Profit per unit of gazing land
B. Profit per unit of animal
C. Profit per unit of feed
D. Others

17. What are the traits which have more emphasis/ stress on your production systems? (Rank)
A. Production traits
B. Reproduction traits
C. Type traits/ conformation traits
D. Secondary traits (longevity, udder health, temperament, milking speed)

18. What type of production traits evaluated in your production system? (Rank)
A. Milk yield
B. Fat yield
C. Protein yield

19. What type of type/conformation traits evaluated in production systems? (Rank)
A. Angularity/ dairy form
B. Chest depth
C. Rump width
D. Rear leg set
E. Udder depth
F. Teat length
G. Rear teat placement 
H. Front teat placement

I. Fore udder attachment

J. Rear udder height

20. What are the criteria to cull your dairy cattle in your production system? (Rank)
A. Age
B. Low milk yield
C. Late age at first service
D. Poor body structure
E. Health problem
F. Difficulty in birth

21. What is your selection goal in your production system?

22. What are the economically traits for milk composition? (Rank)
A. Milk yield
B. Protein yield
C. Fat yield
D. Somatic cell count

23. What are the economically traits for reproduction traits? (Rank)
A. Number of insemination
B. Days in milk
C. Calving ease
D. Replacement rate adjusted for milk yield
E. Rate of stillbirths

24. What are the economically traits for longevity? (Rank)
A. Health cost
B. Replacement rate
C. Milking time

25. What are the economically traits for udder health? (Rank)
A. Replacement rate
B. Milk quality
C. Milk yield
D. Mastitis treatment cost

26. What are the economically traits for cow comfort? (Rank)
A. Longevity 
B. Bacterial count

C. Treatment cost

D. Milk yield

27. What are the economically traits for milk ability? (Rank)
A. Residual feed intake
B. Expected cow maintenance

28. What are the economically traits for your livestock environment? (Rank)
A. Environmental cost
B. Resistance to parasites

29. What are the economically traits for feed costs? (Rank)
A. Expected feed maintenance
B. Residual feed intake
C. Nitrogen balance

30. What are the selection criteria for the reproduction group traits in your dairy farm? (Rank)
A. Heifer pregnancy rate
B. Age at puberty
C. Lactation length
D. Age at first calving
E. Services/conception
F. Calving interva
G. Days open
H. Days to first service
I. Body condition score
J. Milk progesterone
K. Milk urea nitrogen
L. Calving ease score
M. Birth weight
N. Gestation length
O. Stillbirth
P. Pelvic measurements
Q. Rump angle
R. Rump width

31. What are the selection criteria for the longevity group traits in your dairy farm? (Rank)
A. Herd life
B. Number of lactations
C. Stayability
D. Length of productive life
E. Survival rate
F. Type traits 
32. What are the selection criteria for the cow comfort group traits in your dairy farm? (Rank)
A. Disease incidence
B. Somatic cell count (SCC)
C. Bovine Lymphocyte
D. Antigens (BoLA)
E. Immune response to antigen injection
F. Serum lysozyme activity
G. Serum haemolytic complement
H. Efficiency of phagocytosis
I. Calcium mobilization
J. Plasma concentration of glucose, ketones, insulin, thyroxine
K. Tick count
L. Faecal egg count
M. Molecular markers
N. Type traits

33. What are the selection criteria for the udder health group traits in your dairy farm? (Rank)
A. Incidence of mastitis
B. Test day Somatic Cell
C. Score (SCS)
D. Milking speed
E. Udder type traits
F. Electrical conductivity
G. Lactose concentration
H. Bovine serum albumin concentration
I. Concentration of chloride
J. sodium or potassium
K. Markers of immune response

34. What are the selection criteria for the milk ability group traits in your dairy farm? (Rank)
A. Milking speed scores
B. Kilograms milk per minute
C. Temperament scores
D. Approachability to humans
E. Flight distance from humans
F. Flinch, step \& kick behavior
G. Linear type scores
H. Residual milk
I. Heart rate

35. What are the selection criteria for the environmental cleanliness group 
traits in your dairy farm? (Rank)
A. Milk Urea Nitrogen
B. Nutrient balance
C. Methane/greenhouse gases
D. Tick counts
E. Faecal egg counts 